\title{
Indacaterol on dyspnea in chronic obstructive pulmonary disease: a systematic review and meta-analysis of randomized placebo-controlled trials
}

\author{
Jiangna $\operatorname{Han}^{1,4^{*}}$, Lu Dai ${ }^{2}$ and Nanshan Zhong ${ }^{3}$
}

\begin{abstract}
Background: Indacaterol is a novel, once-daily (od), inhaled, long-acting $\beta_{2}$-agonist bronchodilator for maintenance treatment of airflow limitation in patients with COPD. The aim of this study was to evaluate the efficacy of indacaterol on dyspnea, using available randomized placebo-controlled trials.

Methods: A systematic search was made of MEDLINE, EMBASE, the Cochrane trials databases, and a manual search of journals. Randomized placebo-controlled trials of 12 weeks or more comparing indacaterol with placebo were reviewed, and eligible studies were included in a meta-analysis. The odds ratio (OR) for likelihood of achieving TDI score $\geq 1$ after 12 weeks of treatment was used as an outcome measure to compare indacaterol to placebo.

Results: Six trials were included in the analysis. Relative to placebo, the overall ORs for response were: indacaterol $75 \mu \mathrm{g}$ od 1.784 (95\% Cl 1.282 to 2.482); indacaterol $150 \mu \mathrm{g}$ od 2.149 (95\% Cl 1.746 to 2.645); and indacaterol $300 \mu \mathrm{g}$ od 2.458 ( $95 \% \mathrm{Cl} 2.010$ to 3.006). Overall OR for response in TDI tended to increase with higher indacaterol doses.

Conclusions: Patients receiving indacaterol had clinically significant improvements in symptoms of dyspnea compared to placebo. Incremental benefits in TDI were observed with increasing doses. Indacaterol may provide patients and physicians with a useful treatment option in symptomatic patients with dyspnea.
\end{abstract}

Keywords: Breathlessness, Baseline dyspnea index, Transition dyspnea index, Meta-analysis, COPD

\section{Background}

The mortality, morbidity and economic burden of chronic obstructive pulmonary disease (COPD) is well documented [1,2]. Dyspnea as a cardinal symptom of COPD is a major cause of disability and anxiety associated with the disease, prompting the medical community to pursue effective treatments for the relief of dyspnea [3]. Recent guidelines recommend the regular use of inhaled long-acting bronchodilators to alleviate dyspnea in patients with symptomatic disease, with the addition of inhaled corticosteroids for patients who experience repeated exacerbations $[1,2]$.

\footnotetext{
* Correspondence: Janet_Han2000@hotmail.com

'Department of Pneumology, Peking Union Medical College Hospital, Peking Union Medical College, Chinese Academy of Medical Sciences, Beijing, China ${ }^{4}$ Department of Pneumology, Peking Union Medical College Hospital, Shuaifuyuan No. 1, Beijing 100730, China

Full list of author information is available at the end of the article
}

Indacaterol as a novel, once-daily (od), inhaled, longacting $\beta_{2}$-agonist provides sustained bronchodilation for patients with moderate to severe COPD, with a rapid onset following the first dose $[4,5]$. It has been recently approved in Europe at doses of $150 \mu \mathrm{g}$ and $300 \mu \mathrm{g}$ od, in the United States at $75 \mu \mathrm{g}$ od, and in China at $150 \mu \mathrm{g}$ od for maintenance treatment of airflow limitation in patients with COPD. A number of randomized clinical trials suggest that indacaterol may improve dyspnea in patients with stable COPD, as indicated by changes in transition dyspnea index (TDI) [5-10]. However, all of these trials were statistically powered on forced expiratory volume in 1 second $\left(\mathrm{FEV}_{1}\right)$ as a primary endpoint. The outcome measure of TDI was included as one of the secondary endpoints in these trials, and so might not have been adequately powered. 
Therefore, we undertook a systematic review and metaanalysis of available randomized placebo-controlled studies to assess the efficacy of indacaterol on the important clinical outcome of dyspnea. The objectives of this metaanalysis were to combine data from existing randomized placebo-controlled trials, to use the number of patients achieving the minimum clinically important difference (MCID) for TDI score $\geq 1$ as an outcome measure, and to evaluate the efficacy of once-daily indacaterol of licensed $75 \mu \mathrm{g}, 150 \mu \mathrm{g}$, or $300 \mu \mathrm{g}$ doses relative to placebo on dyspnea in patients with stable COPD.

\section{Methods}

\section{Data sources and selection criteria}

We identified published studies between January 2007 and May 2012 from MEDLINE, EMBASE, and the Cochrane Controlled Trials Register (CENTRAL) databases using the terms indacaterol, long-acting $\beta_{2}$-agonist AND chronic obstructive pulmonary disease. We performed a search of relevant files from the Novartis trials results database (http://www.novctrd.com/ctrdWeb App/clinicaltrialrepository/public/login.jsp). We also per formed a manual search of references cited in published original and review articles, and in clinical practice guidelines. Trials published solely in abstract form were excluded because they contain preliminary and rudimentary information and may not provide enough details to allow full analysis. Two reviewers (JNH and LD) then independently screened potentially relevant trials from titles and abstracts. Using the full texts as necessary, the two reviewers independently identified eligible articles for full review. Finally, we reviewed eligible articles to determine whether they qualified for meta-analysis. Differences were resolved by discussion.

To be included, studies had to meet all the following criteria: a) target population of stable COPD consistent with American Thoracic Society/European Respiratory Society [11] or Global Initiative for Chronic Obstructive Lung Disease (GOLD) diagnostic criteria [12]; b) randomized placebo-controlled trials comparing indacaterol $75 \mu \mathrm{g}, 150 \mu \mathrm{g}$, or $300 \mu \mathrm{g}$ od with placebo; c) studies that followed patients for 12 weeks or more after randomization; d) studies that included assessment of dyspnea by transition dyspnea index (TDI) in outcome measures.

\section{Data extraction}

Two reviewers independently read each article that met inclusion criteria and performed data extraction using a pre-designed data collection form. Missing data were obtained from the manufacturer. Disagreement and uncertainty were solved by discussion. Consensus was reached for all data. Data extracted from each article included: first author's name and year of publication; study design; treatment arms; number of patients; treatment duration; baseline clinical characteristics including age, gender, smoking history, post-bronchodilator spirometry, and total score of the baseline dyspnea index (BDI). The outcome measure of TDI was recorded as total score and as the number of patients with TDI $\geq 1$.

\section{Baseline dyspnea index (BDI) and transition dyspnea index (TDI)}

Dyspnea is often measured using the BDI and TDI, a tool recommended by regulatory authorities for inclusion in clinical trials of treatments for COPD [13]. The BDI and TDI, as multidimensional instruments, each has three domains: functional impairment, magnitude of task, and magnitude of effort [14]. The BDI domains measure baseline dyspnea severity, and are rated from 0 (severe) to 4 (unimpaired) and summed to provide a BDI total score of 0 to 12 , with a lower score indicating more severe dyspnea. The TDI domains measure change from the baseline dyspnea index (BDI) over time, rated on a scale of +3 (major improvement) to -3 (major deterioration). The TDI has been shown to be valid, reliable and responsive $[14,15]$. The minimum clinically important difference (MCID) for the TDI is an improvement from the BDI score of $\geq 1$ unit $[16,17]$.

\section{Statistical analyses}

Odds ratio (OR) for likelihood of achieving TDI score $\geq 1$ after 12 weeks of treatment was used as a measure to compare indacaterol relative to placebo. We calculated pooled ORs with the DerSimonian-Laird random effects model [18], usually regarded as more appropriate than other statistical approaches when potential heterogeneity is present between studies $[19,20]$. We performed separate analyses for indacaterol $75 \mu \mathrm{g}$ versus placebo, indacaterol $150 \mu \mathrm{g}$ versus placebo, and indacaterol $300 \mu \mathrm{g}$ versus placebo. We calculated the $95 \%$ confidence intervals around the ORs, and assessed heterogeneity across studies with the chi-square test and $I^{2}$ ( $\mathrm{p}<0.10, I^{2}>$ $25 \%)$. We then created forest plots of the individual studies and combined estimates. All analyses were performed with meta-analysis software (MetaAnalyst version beta 3.13, Tufts Medical Center, Boston, Massachusetts).

\section{Results}

\section{Characteristics of included studies}

Six studies met the inclusion criteria [5-9], the designs of which are summarized in Table 1 . The studies varied from 12 to 52 weeks in duration, and so to permit comparison across trials, assessments at 12 weeks of treatment were used for the 52-week study [6] and for two 26-week studies [5,7]. We did not consider data from tiotropium, formoterol, and 
Table 1 Summary of study designs for the studies included in this meta-analysis

\begin{tabular}{|c|c|c|c|c|}
\hline Study & Design & $\begin{array}{l}\text { Treatment } \\
\text { arms }\end{array}$ & $\begin{array}{l}\text { Number of } \\
\text { patients }\end{array}$ & $\begin{array}{l}\text { Treatment } \\
\text { duration }\end{array}$ \\
\hline \multirow[t]{4}{*}{$\begin{array}{l}\text { Donohue } \\
{[5]}\end{array}$} & $\begin{array}{l}\text { Phase III, randomized, double-blind (indacaterol and placebo) or open-label } \\
\text { (tiotropium), placebo-controlled, parallel-group, multicentre }\end{array}$ & $\begin{array}{l}\text { Indacaterol } \\
150 \mu \mathrm{g} \mathrm{od}\end{array}$ & $\begin{array}{l}1683 \\
\text { randomized; }\end{array}$ & 26 weeks \\
\hline & & $\begin{array}{l}\text { Indacaterol } \\
300 \mu \mathrm{g} \mathrm{od}\end{array}$ & $\begin{array}{l}1665 \text { evaluable } \\
\text { for efficacy }\end{array}$ & \\
\hline & & $\begin{array}{l}\text { Tiotropium } 18 \\
\mu \mathrm{g} \text { od }\end{array}$ & & \\
\hline & & Placebo & & \\
\hline \multirow[t]{4}{*}{ Dahl [6] } & $\begin{array}{l}\text { Phase III, randomized, double-blind, double-dummy, placebo-controlled, parallel-group } \\
\text {, multicentre }\end{array}$ & $\begin{array}{l}\text { Indacaterol } \\
300 \mu \mathrm{g} \mathrm{od}\end{array}$ & $\begin{array}{l}1732 \\
\text { randomized; }\end{array}$ & 52 weeks \\
\hline & & $\begin{array}{l}\text { Indacaterol } \\
600 \mu \mathrm{g} \text { od }\end{array}$ & $\begin{array}{l}1600 \text { evaluable } \\
\text { for efficacy }\end{array}$ & \\
\hline & & $\begin{array}{l}\text { Formoterol } 12 \\
\mu \mathrm{g} \text { bid }\end{array}$ & & \\
\hline & & Placebo & & \\
\hline \multirow[t]{3}{*}{$\begin{array}{l}\text { Kornmann } \\
{[7]}\end{array}$} & $\begin{array}{l}\text { Phase III, randomized, double-blind, double-dummy, placebo-controlled, parallel-group } \\
\text {, multicentre }\end{array}$ & $\begin{array}{l}\text { Indacaterol } \\
150 \mu \mathrm{g} \mathrm{od}\end{array}$ & $\begin{array}{l}1002 \\
\text { randomized; }\end{array}$ & 26 weeks \\
\hline & & $\begin{array}{l}\text { Salmeterol } 50 \\
\mu \mathrm{g} \text { bid }\end{array}$ & $\begin{array}{l}998 \text { evaluable } \\
\text { for efficacy }\end{array}$ & \\
\hline & & Placebo & & \\
\hline \multirow[t]{2}{*}{$\begin{array}{l}\text { Gotfried-1 } \\
{[8]}\end{array}$} & $\begin{array}{l}\text { Phase III, randomized, double-blind, placebo-controlled, parallel-group, in the United } \\
\text { States }\end{array}$ & $\begin{array}{l}\text { Indacaterol } 75 \\
\mu \mathrm{g} \mathrm{od}\end{array}$ & 323 randomized; & 12 weeks \\
\hline & & Placebo & $\begin{array}{l}323 \text { evaluable } \\
\text { for efficacy }\end{array}$ & \\
\hline \multirow[t]{2}{*}{$\begin{array}{l}\text { Gotfried-2 } \\
{[8]}\end{array}$} & $\begin{array}{l}\text { Phase III, randomized, double-blind, placebo-controlled, parallel-group, in the United } \\
\text { States }\end{array}$ & $\begin{array}{l}\text { Indacaterol } 75 \\
\mu \mathrm{g} \mathrm{od}\end{array}$ & 318 randomized; & 12 weeks \\
\hline & & Placebo & $\begin{array}{l}317 \text { evaluable } \\
\text { for efficacy }\end{array}$ & \\
\hline \multirow[t]{3}{*}{$\begin{array}{l}\text { Kinoshita } \\
{[9]}\end{array}$} & $\begin{array}{l}\text { Phase III, randomized, double-blind, placebo-controlled, parallel-group, in six Asian } \\
\text { areas }\end{array}$ & $\begin{array}{l}\text { Indacaterol } \\
150 \mu \mathrm{g} \mathrm{od}\end{array}$ & 347 randomized; & 12 weeks \\
\hline & & $\begin{array}{l}\text { Indacaterol } \\
300 \mu \mathrm{g} \text { od }\end{array}$ & $\begin{array}{l}347 \text { evaluable } \\
\text { for efficacy }\end{array}$ & \\
\hline & & Placebo & & \\
\hline
\end{tabular}

od = once-daily; bid = twice-daily.

salmeterol arms for the current meta-analysis, since data for each of these arms would be provided from one study.

Table 2 illustrates patient populations and baseline characteristics. Of the six studies providing the data for the meta-analysis, four had similar inclusion criteria [5-7,9], recruiting male and female patients aged $\geq 40$ years with a clinical diagnosis of moderateto-severe COPD as per the GOLD 2005 criteria and a smoking history of $\geq 20$ pack-years. Postbronchodilator $\mathrm{FEV}_{1}$ was to be $<80 \%$ and $\geq 30 \%$ predicted and post-bronchodilator $\mathrm{FEV}_{1} /$ forced vital capacity $<70 \%$ [5-7,9]. The two identical indacaterol $75 \mu \mathrm{g}$ trials enrolled patients with moderate-to-severe COPD defined at that time using GOLD 2008 criteria, aged $\geq 40$ years and with a smoking history of $\geq 10$ packyears [8].

\section{Dyspnea - BDI and TDI}

In all trials included in the meta-analysis, dyspnea was measured at baseline using the BDI. As illustrated in Table 2, patients had moderate severity of dyspnea at baseline with mean BDI total scores ranging from 5.81 to 7.67. After 12 weeks of treatment, dyspnea was measured using the TDI (Table 3), which captured changes from baseline. Data are presented as mean TDI total scores and as the number of patients with TDI score $\geq 1$ unit. Results were analyzed for the number of patients responding with a change of TDI equal to or greater than the MCID ('responder analysis') (Table 3).

\section{Indacaterol $75 \boldsymbol{\mu g}$ versus placebo}

Two randomized placebo-controlled studies had identical entry criteria and study designs, which compared indacaterol $75 \mu \mathrm{g}$ once daily with placebo after 12 weeks 
Table 2 Patient characteristics at baseline in the individual studies

\begin{tabular}{|c|c|c|c|c|c|c|c|c|c|}
\hline Study & Treatment arms & $\begin{array}{l}\text { Patients, } \\
\mathrm{n}^{\mathrm{a}}\end{array}$ & $\begin{array}{l}\text { Age, } \\
\text { years }\end{array}$ & $\begin{array}{l}\text { Male, } n \\
(\%)\end{array}$ & $\begin{array}{l}\text { Smoking history, } \\
\text { pack-years }\end{array}$ & $\mathrm{FEV}_{1}, \mathrm{~L}^{\mathrm{b}}$ & $\begin{array}{l}\text { FEV }_{1}, \% \\
\text { pred }^{\mathbf{b}}\end{array}$ & $\begin{array}{l}\mathrm{FEV}_{1} / \mathrm{FVC}, \\
\%^{\mathrm{b}}\end{array}$ & $\begin{array}{l}\text { BDI total } \\
\text { score }^{c}\end{array}$ \\
\hline \multirow[t]{4}{*}{$\begin{array}{l}\text { Donohue } \\
{[5]}\end{array}$} & $\begin{array}{l}\text { Indacaterol } 150 \\
\mu \mathrm{g} \text { od }\end{array}$ & 416 & $\begin{array}{l}63.4(40, \\
87)\end{array}$ & $259(62.3)$ & $48.3(20,150)$ & $\begin{array}{l}1.52(0.62 \\
3.45)\end{array}$ & $\begin{array}{l}56.1(29.3 \\
116.6)\end{array}$ & $\begin{array}{l}53.0(24.4 \\
69.7)\end{array}$ & $6.56(0,12)$ \\
\hline & $\begin{array}{l}\text { Indacaterol } 300 \\
\text { mg od }\end{array}$ & 416 & $\begin{array}{l}63.3(40, \\
88)\end{array}$ & $263(63.2)$ & $50.8(13,208)$ & $\begin{array}{l}1.53(0.57 \\
3.14)\end{array}$ & $\begin{array}{l}56.3(21.3 \\
90.0)\end{array}$ & $\begin{array}{l}52.6(25.7 \\
69.5)\end{array}$ & $6.52(0,12)$ \\
\hline & $\begin{array}{l}\text { Tiotropium } 18 \mu \mathrm{g} \\
\text { od }\end{array}$ & 415 & $\begin{array}{l}64.0(41 \\
85)\end{array}$ & $269(64.8)$ & $50.0(20,180)$ & $\begin{array}{l}1.45(0.48 \\
3.00)\end{array}$ & $\begin{array}{l}53.9(23.6 \\
132.3)\end{array}$ & $\begin{array}{l}52.7(24.7 \\
72.6)\end{array}$ & $6.57(0,12)$ \\
\hline & Placebo & 418 & $\begin{array}{l}63.6(41 \\
84)\end{array}$ & $255(61.0)$ & $49.7(20,156)$ & $\begin{array}{l}1.51(0.53 \\
2.98)\end{array}$ & $\begin{array}{l}56.1(28.4, \\
95.1)\end{array}$ & $\begin{array}{l}53.4(24.0 \\
69.9)\end{array}$ & $6.39(0,12)$ \\
\hline \multirow[t]{4}{*}{ Dahl [6] } & $\begin{array}{l}\text { Indacaterol } 300 \\
\text { g od }\end{array}$ & 437 & $\begin{array}{l}63.9(40, \\
87)\end{array}$ & $351(80.3)$ & $48.6(20,600)$ & $\begin{array}{l}1.48(0.44 \\
2.95)\end{array}$ & $\begin{array}{l}52.8(23.5 \\
101.4)\end{array}$ & $\begin{array}{l}51.1(27.7 \\
90.1)\end{array}$ & $6.62(0,12)$ \\
\hline & $\begin{array}{l}\text { Indacaterol } 600 \\
\text { pg od }\end{array}$ & 425 & $\begin{array}{l}62.9(40, \\
87)\end{array}$ & $327(76.9)$ & $53.6(20,900)$ & $\begin{array}{l}1.48(0.55 \\
2.91)\end{array}$ & $\begin{array}{l}51.6(24.0, \\
84.2)\end{array}$ & $\begin{array}{l}51.1(15.8, \\
84.4)\end{array}$ & $6.57(0,12)$ \\
\hline & $\begin{array}{l}\text { Formoterol } 12 \mu \mathrm{g} \\
\text { bid }\end{array}$ & 434 & $\begin{array}{l}63.6(40, \\
84)\end{array}$ & $348(80.2)$ & $49.0(20,800)$ & $\begin{array}{l}1.50(0.59 \\
3.25)\end{array}$ & $\begin{array}{l}52.9(20.8 \\
100.5)\end{array}$ & $\begin{array}{l}51.3(23.0 \\
96.5)\end{array}$ & $6.46(1,12)$ \\
\hline & Placebo & 432 & $\begin{array}{l}63.2(41 \\
90)\end{array}$ & $352(81.5)$ & $53.3(20,900)$ & $\begin{array}{l}1.52(0.58 \\
3.09)\end{array}$ & $\begin{array}{l}52.9(17.6 \\
96.3)\end{array}$ & $\begin{array}{l}52.1(21.5 \\
80.0)\end{array}$ & $6.52(0,12)$ \\
\hline \multirow[t]{3}{*}{$\begin{array}{l}\text { Kornmann } \\
{[7]}\end{array}$} & $\begin{array}{l}\text { Indacaterol } 150 \\
\text { mg od }\end{array}$ & 330 & $\begin{array}{l}63.2(41 \\
85)\end{array}$ & $238(72.1)$ & $39.6(20,120)$ & $\begin{array}{l}1.48(0.63 \\
2.93)\end{array}$ & $\begin{array}{l}53.9(30.0 \\
104.4)\end{array}$ & $\begin{array}{l}53.5(23.5 \\
76.8)\end{array}$ & $6.74(0,12)$ \\
\hline & $\begin{array}{l}\text { Salmeterol } 50 \mu \mathrm{g} \\
\text { bid }\end{array}$ & 333 & $\begin{array}{l}63.4(41 \\
86)\end{array}$ & $249(74.8)$ & $40.0(20,147)$ & $\begin{array}{l}1.48(0.43 \\
3.18)\end{array}$ & $\begin{array}{l}53.1(17.9 \\
93.4)\end{array}$ & $\begin{array}{l}52.2(18.0 \\
82.2)\end{array}$ & $6.68(0,12)$ \\
\hline & Placebo & 335 & $\begin{array}{l}63.9(42, \\
89)\end{array}$ & $258(77.0)$ & $41.0(20,159)$ & $\begin{array}{l}1.46(0.47 \\
3.20)\end{array}$ & $\begin{array}{l}53.0(12.3 \\
91.0)\end{array}$ & $\begin{array}{l}52.7(20.2, \\
90.9)\end{array}$ & $6.63(0,12)$ \\
\hline \multirow[t]{2}{*}{$\begin{array}{l}\text { Gotfried-1 } \\
{[8]}\end{array}$} & $\begin{array}{l}\text { Indacaterol } 75 \mu \mathrm{g} \\
\text { od }\end{array}$ & 163 & $\begin{array}{l}64.0(44, \\
85)\end{array}$ & $89(54.6)$ & $52.9(10,150)$ & $\begin{array}{l}1.49(0.57 \\
2.92)\end{array}$ & $\begin{array}{l}53.7(30.3 \\
77.3)\end{array}$ & $\begin{array}{l}53.1(31.8 \\
68.3)\end{array}$ & $6.40(2,12)$ \\
\hline & Placebo & 160 & $\begin{array}{l}64.1(40, \\
90)\end{array}$ & $87(54.4)$ & $51.2(10,148)$ & $\begin{array}{l}1.46(0.62, \\
2.77)\end{array}$ & $\begin{array}{l}53.3(29.5 \\
78.7)\end{array}$ & $\begin{array}{l}51.6(25.6, \\
69.1)\end{array}$ & $5.81(1,12)$ \\
\hline \multirow[t]{2}{*}{$\begin{array}{l}\text { Gotfried-2 } \\
{[8]}\end{array}$} & $\begin{array}{l}\text { Indacaterol } 75 \mu \mathrm{g} \\
\text { od }\end{array}$ & 159 & $\begin{array}{l}61.3(40, \\
82)\end{array}$ & $83(52.2)$ & $52.4(11,180)$ & $\begin{array}{l}1.59(0.65 \\
3.39)\end{array}$ & $\begin{array}{l}55.7(29.7 \\
79.3)\end{array}$ & $\begin{array}{l}52.4(22.9, \\
68.6)\end{array}$ & $6.01(0,12)$ \\
\hline & Placebo & 158 & $\begin{array}{l}61.5(42, \\
86)\end{array}$ & $89(56.0)$ & $52.4(10,204)$ & $\begin{array}{l}1.52(0.56 \\
3.00)\end{array}$ & $\begin{array}{l}53.5(30.3 \\
79.4)\end{array}$ & $\begin{array}{l}52.6(28.8 \\
69.1)\end{array}$ & $6.15(1,11)$ \\
\hline \multirow[t]{3}{*}{$\begin{array}{l}\text { Kinoshita } \\
{[9]}\end{array}$} & $\begin{array}{l}\text { Indacaterol } 150 \\
\text { mg od }\end{array}$ & 114 & $\begin{array}{l}66.4(46, \\
83)\end{array}$ & $110(96.5)$ & $51.7(20,196)$ & $\begin{array}{l}1.46(0.70 \\
2.50)\end{array}$ & $\begin{array}{l}55.2(30.0 \\
79.0)\end{array}$ & $\begin{array}{l}50.3(27.0 \\
69.0)\end{array}$ & $7.53(1,12)$ \\
\hline & $\begin{array}{l}\text { Indacaterol } 300 \\
\text { pg od }\end{array}$ & 116 & $\begin{array}{l}67.1(48, \\
86)\end{array}$ & $113(97.4)$ & $54.0(20,150)$ & $\begin{array}{l}1.41(0.68, \\
2.92)\end{array}$ & $\begin{array}{l}53.7(30.0 \\
79.0)\end{array}$ & $\begin{array}{l}48.7(27.0 \\
69.0)\end{array}$ & $7.67(1,12)$ \\
\hline & Placebo & 117 & $\begin{array}{l}66.5(40, \\
88)\end{array}$ & $112(95.7)$ & $49.7(20,160)$ & $\begin{array}{l}1.38(0.55 \\
2.37)\end{array}$ & $\begin{array}{l}52.3(30.0 \\
77.0)\end{array}$ & $\begin{array}{l}47.7(28.0 \\
69.0)\end{array}$ & $7.35(1,12)$ \\
\hline
\end{tabular}

Data are mean (min, max) for age, smoking history, $\mathrm{FEV}_{1}, \mathrm{FEV}_{1} \%$ predicted, and $\mathrm{FEV}_{1} / \mathrm{FVC} \%$ unless stated otherwise.

a Number of patients analysed for efficacy (ITT, modified ITT or FAS).

b Post-bronchodilator spirometry.

c Values for patients who provided data at Week 12

of treatment [8]. A meta-analysis that combined the two studies produced a pooled OR estimate of 1.784 (95\% CI 1.282-2.482) with no evidence of heterogeneity $(P=$ $\left.0.474, \mathrm{I}^{2}=0.000\right)$, indicating that relative to placebo, patients receiving indacaterol $75 \mu \mathrm{g}$ are more likely to achieve TDI score $\geq 1$ after 12 weeks of treatment. Figure 1 shows a forest plot of OR estimates from these studies.

\section{Indacaterol $150 \mu \mathrm{g}$ versus placebo}

Three randomized placebo-controlled trials compared indacaterol $150 \mu \mathrm{g}$ once daily with placebo [5,7,9]. A meta-analysis that combined the three studies produced a pooled OR estimate of 2.149 (95\% CI 1.746-2.645) with no evidence of heterogeneity $\left(P=0.686, \mathrm{I}^{2}=\right.$ 0.000 ), favoring patients who received indacaterol $150 \mu \mathrm{g}$ once daily. Figure 2 shows a forest plot of OR estimates from these studies.

\section{Indacaterol $\mathbf{3 0 0} \boldsymbol{\mu g}$ versus placebo}

Three trials compared indacaterol $300 \mu \mathrm{g}$ once daily with placebo $[5,6,9]$. Figure 3 shows a forest plot of OR estimates from these studies. The combined OR estimate was 2.458 (95\% CI 2.010-3.006) with no evidence of 
Table 3 Indacaterol on dyspnea as measured by the TDI

\begin{tabular}{|c|c|c|c|c|}
\hline \multirow[t]{2}{*}{ Study } & \multirow[t]{2}{*}{ Treatment arms } & \multicolumn{3}{|c|}{ TDI at week 12} \\
\hline & & Patients, $\mathrm{n}^{\mathrm{a}}$ & TDI total score ${ }^{b}$ & Number of patients with TDI $\geq 1$ \\
\hline \multirow[t]{4}{*}{ Donohue [5] } & Indacaterol $150 \mu \mathrm{g}$ od & 355 & $2.09(-8,9)$ & 209 \\
\hline & Indacaterol $300 \mu \mathrm{g}$ od & 363 & $2.40(-9,9)$ & 239 \\
\hline & Tiotropium $18 \mu \mathrm{g}$ od & 360 & $1.89(-6,9)$ & 198 \\
\hline & Placebo & 326 & $1.19(-6,9)$ & 138 \\
\hline \multirow[t]{4}{*}{ Dahl [6] } & Indacaterol $300 \mu \mathrm{g}$ od & 364 & $2.11(-9,9)$ & 229 \\
\hline & Indacaterol $600 \mu \mathrm{g} \mathrm{od}$ & 348 & $2.10(-7,9)$ & 202 \\
\hline & Formoterol $12 \mu \mathrm{g}$ bid & 359 & $1.64(-9,9)$ & 190 \\
\hline & Placebo & 343 & $0.87(-9,9)$ & 138 \\
\hline \multirow[t]{3}{*}{ Kornmann [7] } & Indacaterol $150 \mu \mathrm{g} \mathrm{od}$ & 303 & $2.37(-6,9)$ & 182 \\
\hline & Salmeterol $50 \mu \mathrm{g}$ bid & 296 & $1.60(-6,9)$ & 152 \\
\hline & Placebo & 286 & $0.87(-9,9)$ & 113 \\
\hline \multirow[t]{2}{*}{ Gotfried-1 [8] } & Indacaterol $75 \mu \mathrm{g}$ od & 150 & $1.36(-6,9)$ & 73 \\
\hline & Placebo & 150 & $0.12(-9,9)$ & 48 \\
\hline \multirow[t]{2}{*}{ Gotfried-2 [8] } & Indacaterol $75 \mu \mathrm{g}$ od & 148 & $1.25(-7,9)$ & 69 \\
\hline & Placebo & 149 & $0.83(-6,9)$ & 53 \\
\hline \multirow[t]{3}{*}{ Kinoshita [9] } & Indacaterol $150 \mu \mathrm{g} \mathrm{od}$ & 108 & $2.16(-3,9)$ & 66 \\
\hline & Indacaterol $300 \mu \mathrm{g}$ od & 107 & $2.04(-3,9)$ & 58 \\
\hline & Placebo & 102 & $0.88(-6,9)$ & 40 \\
\hline
\end{tabular}

a Number of patients evaluated for TDI total score at week 12 and included in the responder analysis.

b Values are mean (min, max) of raw and unadjusted TDI total score.

heterogeneity $\left(P=0.525, \mathrm{I}^{2}=0.000\right)$, again favoring patients who received indacaterol $300 \mu \mathrm{g}$ once daily.

\section{Discussion}

The present meta-analyses combined data from existing randomized placebo-controlled trials, using number of patients achieving the minimum clinically important difference (MCID) for TDI score $\geq 1$ as an outcome measure, and evaluated the efficacy of once-daily indacaterol on TDI scores in patients with stable COPD. A favorable effect was consistently obtained for indacaterol over placebo: $75 \mu \mathrm{g}$ od OR 1.784 (95\% CI 1.282 to 2.482); 150 $\mu \mathrm{g}$ od OR 2.149 (95\% CI 1.746 to 2.645); and $300 \mu \mathrm{g}$ od OR 2.458 (95\% CI 2.010 to 3.006). A trend of increasing patient benefit was observed as indacaterol doses increased.

Recent guidelines recommend regular use of bronchodilators, such as indacaterol, as a long-term maintenance treatment of airflow limitation in COPD [1]. The extent to which indacaterol improves airflow in patients with

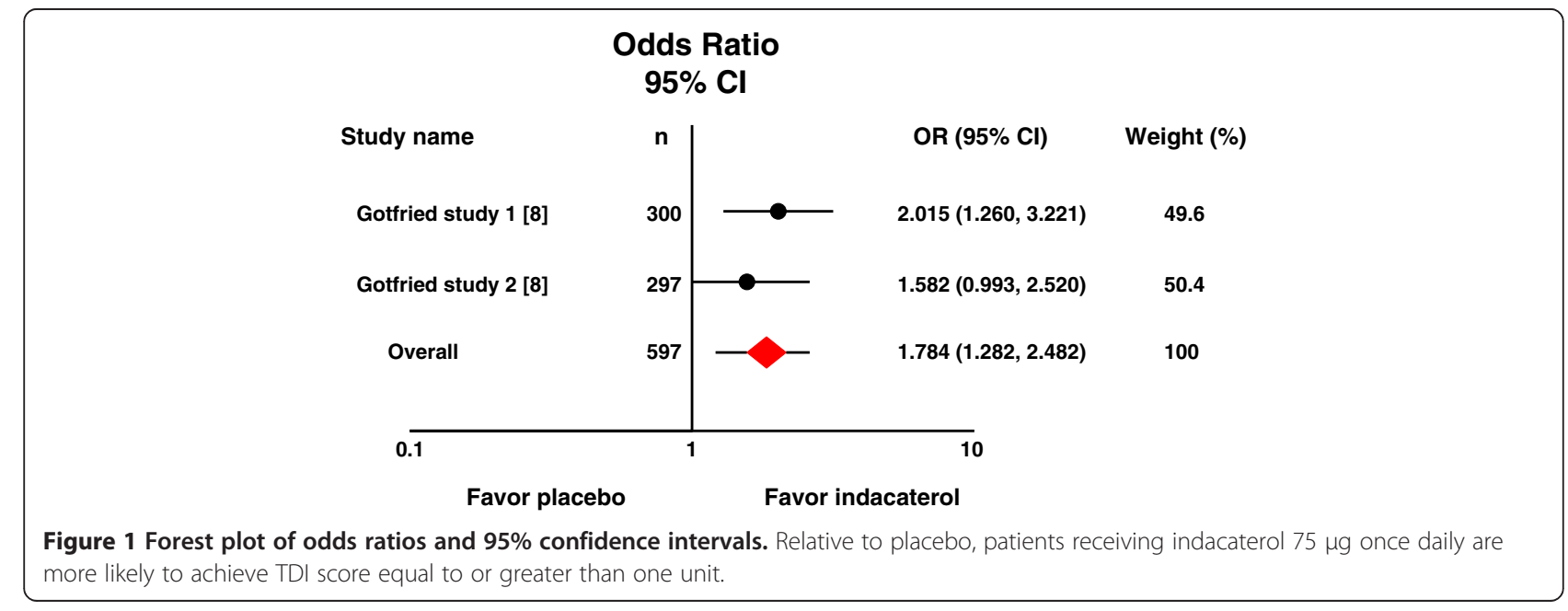




\section{Odds Ratio $95 \% \mathrm{Cl}$}

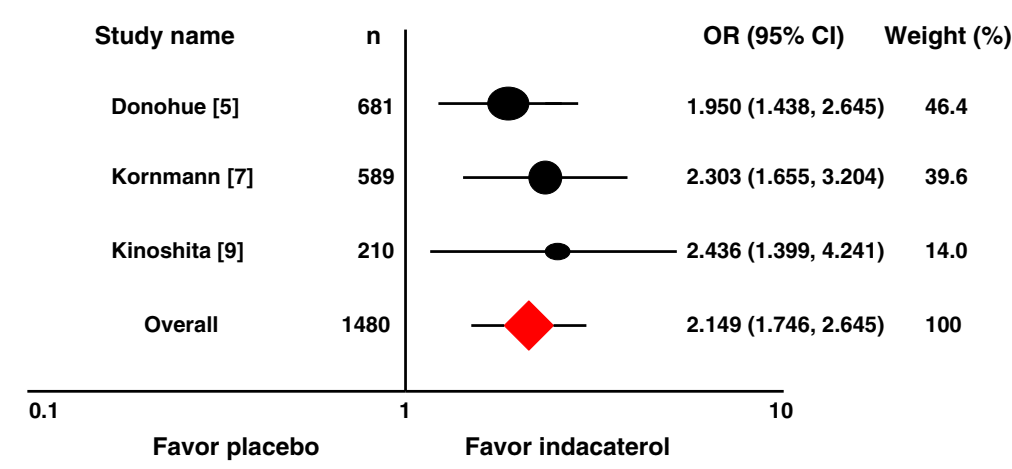

Figure 2 Meta-analysis of three randomized trials compared indacaterol $150 \mu \mathrm{g}$ once daily with placebo. Relative to placebo, patients receiving indacaterol $150 \mu \mathrm{g}$ once daily are more likely to achieve TDI score equal to or greater than one unit.

COPD is well studied [4,5,21-24]. In these phase III studies, indacaterol provided 24-h bronchodilation on once-daily dosing with an effect that was sustained during treatment for up to one year. However, from the patients' viewpoint, it may be more important to know whether this therapy improves dyspnea associated with daily activities, and these meta-analyses of available randomized placebo-controlled trials comparing indacaterol with placebo allows us to examine the efficacy of indacaterol on this important patient outcome. In all trials included in the meta-analyses, dyspnea was assessed using validated multidimensional instruments of BDI and TDI that are widely used to measure treatment effects in COPD [13-17]. When data were analyzed for a pre-determined outcome, i.e. the number of patients responding with a change of TDI equal to or greater than the minimum clinically important difference MCID (a 'responder analysis'), a favorable effect was obtained for all three doses of indacaterol. The overall OR estimates of the meta-analyses are largely consistent with the results from the individual studies, in which the ORs for patients achieving a MCID in the indacaterol group compared with the placebo group varied from 1.582 to 2.015 for the $75 \mu \mathrm{g}$ dose (Figure 1) [8], 1.950 to 2.303 for the $150 \mu \mathrm{g}$ dose (Figure 2) [5,7], and 2.520 to 2.626 for the $300 \mu \mathrm{g}$ dose (Figure 3) $[5,6]$, with a exception of the Asian study [9]. It becomes apparent that patients receiving indacaterol had clinically significant improvements in symptoms of dyspnea compared to placebo over 12 weeks of treatment.

The overall odds ratio for response in TDI appeared to vary depending on indacaterol doses, and tended to increase with increasing indacaterol doses. Additionally, the percentage of patients who exceeded the one unit of the MCID in TDI varied in different indacaterol doses. The percentage in the analysis of indacaterol $75 \mu \mathrm{g}$ once daily was $48 \%$, compared with $34 \%$ in placebo. Compared to placebo, a higher percentage of patients

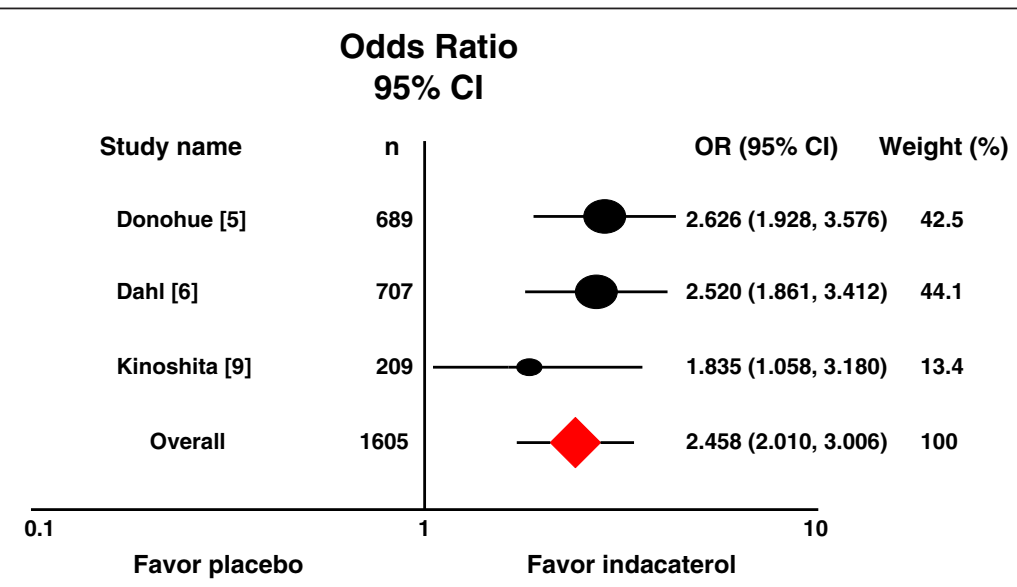

Figure 3 Meta-analysis of three randomized trials compared indacaterol $\mathbf{3 0 0} \mu \mathrm{g}$ once daily with placebo. Relative to placebo, patients receiving indacaterol $300 \mu \mathrm{g}$ once daily are more likely to achieve TDI score equal to or greater than one unit. 
achieved the MCID with the indacaterol $150 \mu \mathrm{g}$ (60\% versus $41 \%$ ) and indacaterol $300 \mu \mathrm{g}$ doses (63\% versus $41 \%)$. Renard and his colleagues recently performed a model based analysis of the bronchodilatory dose response to indacaterol in patients with COPD [25]. The analysis demonstrated that indacaterol dosages of $75 \mu \mathrm{g}$ once daily and above achieved minimal clinically important improvements in predicted trough $\mathrm{FEV}_{1}$ response, although dosages of $150 \mu \mathrm{g}$ and $300 \mu \mathrm{g}$ once daily provided optimum bronchodilation. The analysis also demonstrated that disease severity, as determined by $\mathrm{FEV}_{1}$, significantly affected dose response, suggesting that higher doses may be required in patients with more severe COPD to achieve optimal reduction of dyspnea.

In six trials included in the meta-analysis $(n=5405)$, patients with COPD who received indacaterol $75 \mu \mathrm{g}$, or $150 \mu \mathrm{g}$, or $300 \mu \mathrm{g}$ od had a significantly higher trough $\mathrm{FEV}_{1}$ than placebo after at least 12 weeks, with indacaterol increasing trough $\mathrm{FEV}_{1}$ by $120 \mathrm{ml}$ to $200 \mathrm{ml}$ over placebo at week 12 [5-9]. The overall improvement in $\mathrm{FEV}_{1}$, though modest, may be sufficient to decrease the extent of hyperinflation which contributes to the sensation of dyspnea [26-29]. A better indicator of the effect of a bronchodilator on hyperinflation (and therefore the sensation of dyspnea) is perhaps inspiratory capacity. One could hypothesize that the prolonged bronchodilation observed with indacaterol would be associated with reductions of air trapping, and therefore reductions in hyperinflation, which would then be reflected in improvements in the sensation of dyspnea. There are relatively few indacaterol studies that included both an assessment of inspiratory capacity and of dyspnea, however, two short-term exercise studies comparing the $300 \mu \mathrm{g}$ dose of indacaterol with placebo have been published [30,31]. The BDI/TDI was included in one of the studies, an improvement of $182 \mathrm{ml}$ in resting inspiratory capacity after 14 days ( $<0.05$ vs. placebo) was associated with a change of TDI total score of +3.33 $(\mathrm{p}<0.01$ vs. placebo) [31], providing indirect evidence to support the hypothesis.

\section{Conclusions}

Once daily indacaterol provides clinically significant improvements in dyspnea compared with placebo after 12 weeks of treatment. Incremental benefits in TDI were observed with increasing doses of indacaterol. Indacaterol may provide patients and physicians with a useful treatment option in symptomatic patients with dyspnea. Further studies, that investigate the relationship between disease severity as determined by $\mathrm{FEV}_{1}$ and dose response to indacaterol in terms of dyspnea, are needed to specifically address the question whether higher doses are required in patients with more severe COPD to achieve optimal reduction of dyspnea.

\section{Abbreviations}

BDI: Baseline dyspnea index; COPD: Chronic obstructive pulmonary disease; $\mathrm{FEV}_{1}$ : Forced expiratory volume in 1 second; FVC: Forced vital capacity; GOLD: Global initiative for obstructive lung disease; MCID: Minimal clinically important difference; TDI: Transition dyspnea index; RCTs: Randomized controlled trials.

\section{Competing interests}

JNH has no conflict of interests to declare. LD is an employee of Novartis China. NSZ has no conflict of interests to declare.

\section{Authors' contributions}

$\mathrm{JNH}, \mathrm{LD}$ and NSZ were involved in the concept and design of this article and the interpretation of the data. JNH was responsible for analysis of data. All authors were participated in all stages of developing the manuscript. All authors revised the manuscript critically for important intellectual content, and gave their final approval of the version to be published.

\section{Acknowledgements}

The authors thank David Young (Novartis, Horsham, West Sussex) for providing detailed information of various studies and for his help in the preparation of the manuscript.

This study was funded by National Science and Technology Infrastructure Program for the $12^{\text {th }}$ Five-Year Plan.

\section{Author details}

${ }^{1}$ Department of Pneumology, Peking Union Medical College Hospital, Peking Union Medical College, Chinese Academy of Medical Sciences, Beijing, China. ${ }^{2}$ Medical Affairs, Beijing Novartis Pharma Co., Ltd, BeijingChina. ${ }^{3}$ State Key Laboratory of Respiratory Disease, First Affiliated Hospital, Guangzhou Medical College, Guangzhou, China. ${ }^{4}$ Department of Pneumology, Peking Union Medical College Hospital, Shuaifuyuan No. 1, Beijing 100730, China.

Received: 12 January 2013 Accepted: 19 April 2013

Published: 25 April 2013

\section{References}

1. Global Initiative for Obstructive Lung Disease (GOLD): Global strategy for the diagnosis, management, and prevention of chronic obstructive pulmonary disease. 2011. http://www.goldcopd.org/Guidelines/ guidelines-gold-summary-2011.html.

2. Qaseem A, Wilt TJ, Weinberger SE, Hanania NA, Criner G, van der Molen T, Marciniuk DD, Denberg T, Schünemann H, Wedzicha W, MacDonald R, Shekelle P: Diagnosis and management of stable chronic obstructive pulmonary disease: a clinical practice guideline update from the American College of Physicians, American College of Chest Physicians, American Thoracic Society, and European Respiratory Society. Ann Intern Med 2011, 155:179-191.

3. Mahler DA, Selecky PA, Harrod CG, Benditt JO, Carrieri-Kohlman V, Curtis JR, Manning HL, Mularski RA, Varkey B, Campbell M, Carter ER, Chiong JR, Ely EW, Hansen-Flaschen J, O'Donnell DE, Waller A: American College of Chest Physicians consensus statement on the management of dyspnea in patients with advanced lung or heart disease. Chest 2010, 137:674-691.

4. Balint B, Watz H, Amos C, Owen R, Higgins M, Kramer B: Onset of action of indacaterol in patients with COPD: Comparison with salbutamol and salmeterol-fluticasone. Int J Chron Obstruct Pulmon Dis 2010, 5:311-318.

5. Donohue JF, Fogarty C, Lötvall J, Mahler DA, Worth H, Yorgancioglu A, lqbal A, Swales J, Owen R, Higgins M, Kramer B: Once-daily bronchodilators for chronic obstructive pulmonary disease. Am J Respir Crit Care Med 2010, 182:155-162.

6. Dahl R, Chung KF, Buhl R, Magnussen H, Nonikov V, Jack D, Bleasdale P, Owen $R$, Higgins M, Kramer B: Efficacy of a new once-daily long-acting inhaled beta2-agonist indacaterol versus twice-daily formoterol in COPD. Thorax 2010, 65:473-479.

7. Kornmann O, Dahl R, Centanni S, Dogra A, Owen R, Lassen C, Kramer B: Once-daily indacaterol versus twice-daily salmeterol for COPD: a placebo-controlled comparison. Eur Respir J 2011, 37:273-279.

8. Gotfried MH, Kerwin EM, Lawrence D, Lassen C, Kramer B: Efficacy of indacaterol $75 \mu \mathrm{g}$ once-daily on dyspnea and health status: results of two double-blind, placebo-controlled 12-week studies. COPD 2012, 9:1-8. 
9. Kinoshita M, Lee SH, Hang LW, Ichinose M, Hosoe M, Okino N, Prasad N, Kramer B, Fukuchi Y: Efficacy and safety of indacaterol 150 and $300 \mu \mathrm{g}$ in chronic obstructive pulmonary disease patients from six Asian areas including Japan: a 12-week, placebo-controlled study. Respirology 2012, 17:379-389.

10. Kerwin EM, Gotfried MH, Lawrence D, Lassen C, Kramer B: Efficacy and tolerability of indacaterol $75 \mu \mathrm{g}$ once daily in patients aged $\geq 40$ years with chronic obstructive pulmonary disease: results from 2 double-blind, placebo-controlled 12-week studies. Clin Ther 2011, 33:1974-1984.

11. Celli BR, MacNee W, Agusti A, Anzueto A, Berg B, Buist AS, Calverley PMA, Chavannes N, Dillard T, Fahy B, Fein A, Heffner J, Lareau S, Meek P, Martinez F, McNicholas W, Muris J, Austegard E, Pauwels R, Rennard S, Rossi A, Siafakas N, Tiep B, Vestbo J, Wouters E, ZuWallack R: Standards for the diagnosis and treatment of patients with COPD: a summary of the ATS/ ERS position paper. Eur Respir J 2004, 23:932-946.

12. Global Initiative for Obstructive Lung Disease (GOLD): Global strategy for the diagnosis, management, and prevention of chronic obstructive pulmonary disease. 2005. http://www.goldcopd.org/search.html?q=GOLD+2005 tupdate\&user.

13. Jones P, Lareau S, Mahler DA: Measuring the effects of COPD on the patient. Respir Med 2005, 99(Suppl B):S11-S18.

14. Mahler DA, Weinberg DH, Wells CK, Feinstein AR: The measurement of dyspnea. Contents, interobserver agreement, and physiologic correlates of two new clinical indexes. Chest 1984, 85:751-758.

15. Witek TJ Jr, Mahler DA: Meaningful effect size and patterns of response of the transition dyspnea index. J Clin Epidemiol 2003, 56:248-255.

16. Witek TJ Jr, Mahler DA: Minimal important difference of the transition dyspnea index in a multinational clinical trial. Eur Respir J 2003, 21:267-272.

17. Mahler DA, Witek TJ Jr: The MCID of the transition dyspnea index is a total score of one unit. COPD 2005, 2:99-103.

18. DerSimonian R, Laird N: Meta-analysis in clinical trials. Contr Clin Trials 1986, 7:177-188.

19. Mosteller F, Colditz GA: Understanding research synthesis (meta-analysis). Annu Rev Publ Health 1996, 17:1-23.

20. Bates MN, Khalakdina A, Pai M, Chang L, Lessa F, Smith KR: Risk of tuberculosis from exposure to tobacco smoke: a systematic review and meta-analysis. Arch Intern Med 2007, 167:335-342.

21. Barnes PJ, Pocock SJ, Magnussen H, lqbal A, Kramer B, Higgins M, Lawrence $D$ : Integrating indacaterol dose selection in a clinical study in COPD using an adaptive seamless design. Pulm Pharmacol Ther 2010, 23:165-171.

22. Vogelmeier C, Ramos-Barbon D, Jack D, Piggott S, Owen R, Higgins M, Kramer B: Indacaterol provides 24-hour bronchodilation in COPD: a placebocontrolled blinded comparison with tiotropium. Respir Res 2010, 11:135.

23. Magnussen $H$, Verkindre $C$, Jack D, Jadayel D, Henley M, Woessner $R$, Higgins M, Kramer B: Indacaterol once-daily is equally effective dosed in the evening or morning in COPD. Respir Med 2010, 104:1869-1876.

24. Chapman KR, Rennard SI, Dogra A, Owen R, Lassen C, Kramer B: Long-term safety and efficacy of indacaterol, a long-acting $B_{2}$-agonist, in subjects with COPD: a randomized, placebo-controlled study. Chest 2011 , 140:68-75.

25. Renard D, Looby M, Kramer B, Lawrence D, Morris D, Stanski DR: Characterization of the bronchodilatory dose response to indacaterol in patients with chronic obstructive pulmonary disease using model-based approaches. Respir Res 2011, 12:54.

26. Cooper CB: Airflow obstruction and exercise. Respir Med 2009, 103:325-334.

27. Hanania NA, Donohue JF: Pharmacologic interventions in chronic obstructive pulmonary disease. Proc Am Thorac Soc 2007, 4:526-534

28. Malerba M, Radaeli A, Morjaria JB: Therapeutic potential for novel untra long-acting $\beta_{2}$-agonists in the management of COPD: biological and pharmacological aspects. Drug Discov Today 2012, 17:496-504.
29. Fuso L, Mores N, Valente S, Malerba M, Montuschi P: Long-acting betaagonists and their association with inhaled corticosteroids in COPD. Curr Med Chem 2013. Epub ahead of print.

30. O'Donnell DE, Casaburi R, Vincken W, Puente-Maestu L, Swales J, Lawrence D, Kramer B: Effect of indacaterol on exercise endurance and lung hyperinflation in COPD. Respir Med 2011, 105:1030-1036.

31. Beeh KM, Wagner F, Khindri S, Drollmann AF: Effect of indacaterol on dynamic lung hyperinflation and breathlessness in hyperinflated patients with COPD. COPD 2011, 8:340-345.

doi:10.1186/1471-2466-13-26

Cite this article as: Han et al.: Indacaterol on dyspnea in chronic obstructive pulmonary disease: a systematic review and meta-analysis of randomized placebo-controlled trials. BMC Pulmonary Medicine 2013 13:26.

\section{Submit your next manuscript to BioMed Central and take full advantage of:}

- Convenient online submission

- Thorough peer review

- No space constraints or color figure charges

- Immediate publication on acceptance

- Inclusion in PubMed, CAS, Scopus and Google Scholar

- Research which is freely available for redistribution 